\title{
DOI: https://doi.org/10.24297/jssr.v15i.8527
}

\section{Reconstruction of Roles and Responsibilities of The Board of Directors in Share Repurchase in Limited Liability Company Based on Fair Values}

\author{
${ }^{1}$ Anis Mashdurohatun ${ }^{2}$ Lenny Mutiara Ambarita ${ }^{3}$ Gunarto \\ ${ }^{1}$ Faculty of Law Unissula Semarang Indonesia \\ ${ }^{2}$ Doctoral program of Law, Faculty of Law Unissula Semarang Indonesia \\ ${ }^{3}$ Faculty of Law Unissula Semarang Indonesia \\ anism@unissula.ac.id
}

\begin{abstract}
This research aims to find out the roles and responsibilities of the board of directors in repurchasing shares in limited companies that have not been fair and to reconstruct the roles and responsibilities of the board of directors in repurchasing shares in limited companies based on fair values. This research is a sociolegal research, that is, an alternative approach that tests doctrinal studies of law. The word 'socio' in sociolegal represents the correlation between the context in which the law is located (an interface with a context within which law exists). It was found that the Board of Directors is jointly and severally liable for losses suffered by shareholders in good faith, arising from repurchases that are null and void due to the law. This does not provide fair/balanced legal protection for the parties. The fair values in buying shares are to provide balanced and proportional legal protection. Reconstruction of the roles and responsibilities of the Board of Directors in the repurchase of shares in a limited company based on fair values by carrying out reconstruction of Article 37 paragraph (3) and (5) of Law Number 40 Year 2007 concerning Limited Liability Companies.
\end{abstract}

Keywords: Roles, Responsibilities, Directors, Liability, Company

\section{Introduction}

Limited Liability Company is a legal entity which is a capital alliance, established based on an agreement, which conducts business activities with authorized capital which is entirely divided into shares and fulfills the requirements stipulated in the laws and implementing regulations. ${ }^{1}$ The provisions bring legal consequences that a limited liability company (hereinafter referred to as the Company) has its own rights, obligations, and assets, separated from the rights, obligations and assets of its founders or shareholders.

The company's Board of Directors (BOD) is the only organ in the company that carries out the company's management functions, and in such management, it carries out the management of the company for the benefit of the company and in accordance with the aims and objectives of the company. ${ }^{2}$ The responsibility is borne by $B O D$ as an entity. Therefore, every BOD's member must be in good faith and full of responsibility for carrying out his/her duties for the benefit of the company. Any negligence or mistake made by one director results in the member of BOD being personally liable for any company losses. Based on this provision, it makes every member of BOD obliged to check and balance the actions of other members. This check and balance method is not intended to cause conflict between BOD's members, but as a means of coordination for all BOD's members. ${ }^{3}$

\footnotetext{
${ }^{1}$ Article 1 number 1 of Law Number 40 of 2007 Concerning Limited Liability Companies

2 Article 92 paragraph (1) of Law Number 40 of 2007 Concerning Limited Liability Companies

${ }^{3}$ Gunawan Widjaja, Board of Directors Responsibility for the Bankruptcy of the Company, (Jakarta: PT. Raja Grafindo Persada, 2003), p. 4
} 
BOD must also be able to interpret and implement company policies in the best interests of the company, advancing the company, increasing the value of the company's shares, generating profits for the company's shares, and generating profits for the company, shareholders and stakeholders. Based on the existing authority (proper purposes), BOD must be able to express and carry out its duties properly, so that the company always runs on the right and proper track. Thus, BOD must be able to prevent the company from illegal actions, contrary to regulations and public interests, and agreements made with other company organs, shareholders, and stakeholders. ${ }^{4}$

Fiduciary duty by Black's Law Dictionary is defined as a duty to act with the highest degree of honesty and loyalty towards another person and in the best interests of the other person (such as the duty that one partner owes to another). ${ }^{5}$

From the above definition, a fiduciary relationship arises when one party does something for the other party's interests by setting aside his own personal interests. BOD's fiduciary duties contain the following principles: ${ }^{6}$

1. BOD in carrying out their duties may not do it for personal or third-party interests without the company's consent and or knowledge;

2. BOD may not take advantage of their position as an administrator to obtain profits, both for themselves and third parties, except with the company's approval;

3. BOD may not use or misuse the company's assets for their own or third parties' interests.

Because the position of BOD is fiduciary, which the UUPT (Law Concerning the Limited Liability Company) recognizes to some extent, BOD's responsibility is of a high degree. They are responsible for not only intentional dishonesty but also the actions of mismanagement, negligence or failure or not doing something important for the company. ${ }^{7}$ In managing the company, BOD is bound not only to what is explicitly stated in the aims and objectives and business activities of the company but also to what can support or expedite their duties (secondary) that is still within the limits permitted or still within the scope of their duties and obligations (intra vires) provided in accordance with habits, fairness, and propriety (no ultra vires). ${ }^{8}$

One way to reduce the rate of share prices that continues to decline is the Share repurchase program. Share repurchase means that the issuer buys the shares that have been offered to the public. The Share repurchase Program is information that must be known to the public so that issuers are required to announce it to the public through newspapers and IDX as a form of information disclosure. Currently, the share repurchase program is regulated by the Financial Services Authority (FSA). In the third week of August 2015, FSA issued Circular Number 22/SEOJK.04/2015 regarding other conditions as market conditions that fluctuated significantly in the implementation of share repurchases issued by issuers or public companies. This is one solution to suppress share prices, so they do not fall too deep. In this circular letter, FSA facilitates companies that will repurchase their shares up to a maximum of $20 \%$ of paid-up capital, and they do not need to obtain the approval from the General Meeting of Shareholders (GMS). The issuers must follow the rules and procedures as determined by the OJK to repurchase their shares. Previously, on August 27, 2013, the FSA also issued a Circular Number 1/SEOJK.04/2013 in connection with other conditions as market conditions that fluctuated significantly in the implementation of share repurchases issued by issuers or public companies. At that time, $\mathrm{JCl}$ (Stock Exchange Composite Index) also experienced a significant decline. The circular also confirms the issuer in repurchasing its share as stipulated in FSA Regulation Number 2/POJK.04/2013.

\footnotetext{
${ }^{4}$ Misahardi Wilamarta, Minority Shareholder Rights in the Context of Good Corporate Governance, (Jakarta: Postgraduate Program, Faculty of Law, University of Indonesia, 2002), p. 135

${ }^{5}$ Bryan A. Garner, Black's Law Dictionary, Eight Edition, (St. Paull-Minn: West Publishing, 2004), p. 545

${ }^{6}$ Chatamarrasjid, Breaking the Company's Veil and Actual Problems with Company Law, (Bandung: Citra Aditya Bakti, 2004), p. 196-197

7 Munir Fuady, Limited Liability Company, New Paradigm, (Bandung: Citra Aditya Bakti, 2003), p. 82

${ }^{8}$ I.G. Ray Wijaya, Corporate Law, (Jakarta: Megapoint Division and Kesaint Blanc, 2000), p. 226
} 
The share repurchase program is also a part of corporate actions and one of the objectives of corporate actions to increase earnings per share because of each share repurchased by an issuer, investors do not get dividends. Thus, the number of net profit sharing of shares is reduced. Another reason for the company to conduct a Share repurchase program is because the share price in the market is already too low (undervalued), while the company estimates the prospects for good performance and is expected to increase share prices. Thus, if the company repurchases the share, it will benefit from capital gains in the future. Regarding the repurchases made by market conditions that have the potential for crisis, Bapepam issues the Regulation Number XI.B.3 issuers or public companies can repurchase their shares through the GMS. ${ }^{9}$ This is very contrary to Article 38 paragraph (1) of UUPT which states that the share repurchase or further transfer may only be carried out based on the approval of the GMS, unless otherwise stipulated in the legislation in the capital market.

The legal problem arising is how is the reconstruction of the roles and responsibilities of BOD in the share repurchase in a limited liability company based fair values.

\section{Research Method}

This type of research used in this dissertation is doctrinal law research, which is a legal research method carried out by examining the statutory materials, library materials or secondary data. In this dissertation, the research is analytical descriptive by collecting data that illustrate or present the facts and data as well as the analysis of research results aimed at obtaining a picture to support legal arguments in a systematic and structured manner based on normative jurisdiction, namely the research analysis based on the provisions of laws and regulations which also refer to supporting facts and theories in the reconstruction of the roles and responsibilities of Board of Directors in the share repurchase of the limited liability company based on fair values.

This research is a sociolegal research, that is, an alternative approach that tests doctrinal studies of law. The word 'socio' in sociolegal represents the relationship between the jurisdictional contexts (an interface with a context within which law exists). ${ }^{10}$

\section{Result and Discussion}

One thing that is closely related to the issue of legal protection for BOD is regarding the Business Judgment Rule. This principle postulates that a director cannot be held personally liable for his actions carried out in his position as the director if he believes that the action taken is the best for the company and is carried out honestly in good faith for the interests of the company. Thus, the Business Judgment Rule is categorized as fair and reasonable wisdom.

Along with the implementation of the two BOD's obligations, simultaneously, the Company's BOD is also required to carry out and maintain:11

1. List of the Company's Shareholders, which contains information regarding share ownership in the company by shareholders;

2. Special Register that contains information about share ownership by the Board of Directors and Commissioners of the Company, along with their families for each share owned in the Company or in other limited liability companies;

3. Minutes of General Meeting of Shareholders and Minutes of Meeting of BOD of the company.

Repurchasing parts or all the shares that have been issued to the public is one of the company's actions. What the issuers do is also a strategy in investing in shares. Repurchase of shares is carried out by issuers or public

\footnotetext{
${ }^{9} \mathrm{http}: / /$ www.tarjoni.com/aturan_buy_back_saham, accessed on October 14, 2018

${ }^{10}$ Sulistyowati Irianto and Shidarta (ed), Legal Research Methods, Constellation and Reflection, (Jakarta: Obor Indonesia Foundation, 2009), p. 175

${ }^{11}$ Ahmad Yani and Gunawan Widjaja, Limited Liability Company, (Jakarta: PT. Raja Grafindo Persada, 2003), p. 105
} 
companies to increase the price of shares that have fallen on the capital market. Repurchase of shares is usually done when the share price is below the real price. In addition, another function of share repurchase is to increase corporate earnings per share and return on equity in a sustainable way that can increase share prices, especially when the Company is facing an issue regarding a decline in its performance that has the potential to reduce the company's share price. One of the factors of holding a share repurchase is to maintain the nominal value of the total paid up and placed capital if a portion of the capital is not owned or bought by anyone on the market within a certain time period. This means that a repurchase of shares can be carried out by the Company in the event of a situation where several shares have been issued by the company, but the shares are idle. Thus, to secure the company's capital and wealth, the shares are then repurchased by the Company.

Share repurchase according to wikipedia.com can be distributed in cash to existing shareholders in exchange for outstanding shares they hold. Share repurchase or share buyback is one step to utilize the remaining retained profit. When a company repurchases its shares, this will reduce the number of outstanding shares held by the public, so that even though the profits generated remain the same, earnings per share will increase. Thus, repurchase of shares, especially when the share price of the company is undervalued will provide a profitable return on investment. Law Number 40 of 2007 tolerates repurchases, for certain purposes. Universally, it also aims to stabilize the national economy of the country. By doing a share repurchase, the company can save its shares previously issued and keep them. After the wheels of the capital market turnaround have improved, then the shares can be republished to the public.

Share repurchase is a form of the duty and responsibility of the company to protect the company's wealth and capital. The benefits may not be felt immediately by the company and shareholder. When the company repurchases its shares, it will reduce the number of shares outstanding by the public, so that even though profits remain the same, the returns from each share (per share) will increase. Therefore, it will benefit the company because of the return on investment.

Some reasons that become the basis for issuers to repurchase their shares in public are as follows: ${ }^{12}$

\section{To maintain the fairness of the share price.}

In the capital market, a company's share price can be used as a good benchmark for the its financial performance, so that it is in a fair and normal condition. The better the financial performance of a company, the share price will also increase. Repurchase of shares can be used as an alternative that can be used by issuers to increase the price of their shares that have fallen on the market. This repurchase results in an increase in earnings per share (EPS) and Return on Equity (ROE) on an ongoing basis which can result in an increase in share prices in the market.

In addition, with share repurchase, shares owned by the public will decrease (supply decreases). As a result, the share price will rise (assuming the number of requests for these shares remains). However, it should be noted that the reason for issuers to repurchase shares is to increase their earning per share because the increase in earnings per share is not caused by an increase in company earnings or profits, but the number of circulating shares decreasing, so that the profit ratio per share or earnings per share has increased. In other words, the rise in share prices of issuers carrying out share repurchase is not caused by an increase in fundamental performance, but the changing supply and demand mechanism of the market.

\section{Psychological Signal to the market.}

The announcement of a share repurchase is expected to be able to transmit a positive signal to the market that the share price may have been undervalued. Thus, investors or the market are expected to react positively to buy shares so that in turn the stock price returns to the level expected by the issuer. When there was a crash in

\footnotetext{
${ }^{12}$ Sally Putri, Juridical Review of the Buyback of Public Company Shares After the Establishment of the Financial Services Authority, Thesis, (Medan: Universitas Sumatera Utara, 2014)
} 
the American capital market in 1987, many large companies announced that they would repurchase (buyback) their shares. This was done to get a positive signal and immediately act positively so that stock prices become relatively stable.

\section{Repurchasing shares for resale.}

Issuers that have repurchased shares may resell their shares on the Exchange. If the shares repurchased can be resold at a price higher than the acquisition price, the difference between the selling price and the repurchase price of the shares is added as Additional Paid-in Capital. This will improve the capital structure of the issuer.

\section{Repurchasing shares to be distributed to employees (ESOP).}

Some companies buy back shares to be distributed to employees as an incentive so that they can continue to work at the company. Such incentives are commonly called the Employee Stock Option Plan (ESOP), which is a kind of incentive program for employees to own shares of the company where they work. Many things can be produced from this ESOP program, including the fact that employees will become more comfortable for a long time (reducing turnover at the company).

\section{To avoid acquisition by other companies because they have abundant cash funds.}

Companies that have good prospects in the future, especially companies that currently have abundant cash funds, are one of the companies that are often targeted for acquisition. As a way of self-defense so as not to be acquired, the company can use its cash funds to repurchase its shares. In advanced stock exchanges, such as the New York Stock Exchange (NYSE), repurchases are often used as a defense strategy to thwart takeovers from other companies that are not preferred by issuers. Usually, issuers who have large cash balances in the balance sheet are often attractive targets for acquisitions. Then, the listed issuers use cash to repurchase their own shares to make them less attractive to be targeted for acquisitions.

\section{Tax considerations.}

Implementation of share repurchase based on tax considerations often occurs, especially in developed countries, because when an investor gets a dividend distribution, the investor will be subject to a tax on income from the dividend. That is, the return given by the issuer to the holder is reduced because of the tax on dividends. This becomes even more crucial when the tax rate charged on dividend income is relatively large. For these reasons, the issuers choose to repurchase (buyback) their shares. Thus, shareholders are given the option to sell shares when investors feel that it would give more real returns that are expected by the investor. Investors will certainly be willing to buy at a price higher than the market price.

\section{Flexibility factor for issuers}

The decision to distribute dividends to shareholders is a well-planned decision regarding timings, available funds, and consideration of other companies' financial conditions. This is different from the dividend decision because the issuer's management has the discretion to set when and how many transactions will be carried out in a share repurchase.

\section{As an effort to save dividends}

Repurchase (buyback) of shares can reduce the number of outstanding shares in the community, so the company can save a lot of dividend distribution when performing stock dividend as repurchased shares are not getting the right to dividends.

When examined from the hierarchy of laws and regulations, UUPM (Capital Market Law) is lex specialis from UUPT which is lex generalis. Therefore, what is regulated in UUPM must refer to UUPT. In carrying out its 
activities in the capital market, the Capital Market Law gives a large position and role to Bapepam. Because share repurchases are not regulated in the Capital Market Law, the Bapepam-Financial Institution Regulation is used because Bapepam is part of the capital market.

Although Bapepam regulations is the lex specialis from the Capital Market Law, because in its preparation there are things that are very contradictory to the temporary UUPT for a regulation to be carried out properly and without causing confusion, the reconstruction of the Capital Market Law and Bapepam-Financial Institution regulations must be carried out. In this case, in terms of the principles and hierarchy of legislation, the validity of the share repurchases carried out without going through the GMS is invalid.

Efforts to carry out reconstruction are primarily a form of legal protection that can be obtained fairly by the parties. This is where the researcher emphasizes the existence of the grounds that are used as a reason for the reconstruction of the roles and responsibilities of BOD in the repurchase of shares in a limited liability company based on fair values by carrying out reconstruction of Article 37 paragraph (3) of Law Number 40 Year 2007 Concerning Limited Liability Companies, that is:

Before reconstruction: BOD is jointly and severally liable for losses suffered by shareholders in good faith, arising from repurchases that are null and void due to the law referred to in paragraph (2). After reconstruction: Article 37 paragraph (3) of Concerning Limited Liability Companies: BOD is jointly and severally liable for losses suffered by shareholders in good faith, arising from repurchases that are null and void due to the law referred to in paragraph (2) after a comparative study of the share repurchase. Addition to Article 37 (5) The share repurchase must be carried out carefully and transparently.

\section{Juridical requirements needed for a company to repurchase its shares are as follows:}

1. The purchase price is taken from the company's net profit.

2. The purchase price does not cause the company's net wealth less than the amount of capital placed plus the required reserves.

3. Repurchase of shares or further transfer can only be done through the mechanism of the company's GMS.

\section{Repurchase of shares issued by Issuers or public companies:}

1. If the repurchased shares have been sold at a lower price, the loss must be clearly disclosed in the statement of income of the issuer or public company.

2. Issuers or public companies whose shares are listed on the stock exchange are prohibited from repurchasing their shares if it will result in a reduction in the number of shares at a certain level that may significantly reduce the liquidity of shares on a basis or fulfill the delisting requirements of the shares on the stock exchange

3. Issuers or public companies can repurchase their shares in accordance with Articles 37, 38 and 39 of Law Number 40 of 2007 concerning Limited Liability Companies without violating the provisions of Articles 91 , 92, 95 and 96 of Law Number 8 of 1995 concerning Capital market.

As explained, Article 62 of UUPT gives the right to every shareholder to ask the company to have its shares purchased at a fair price if it does not approve the company's actions which are detrimental to the shareholders. This right is granted by Article 126 paragraph (2) of UUPT to shareholders who "disagree" with the GMS decision regarding consolidation. If any of the shareholders disagree on the merger, they can ask the company to buy the company's shares at a fair price if it is evident that the consolidation is detrimental to the shareholders concerned. The purchase of shares at a fair price is intended to protect shareholders from unilateral actions. Because shareholders in this case may not be disadvantaged, then if an expert appraiser is used, the share price will be borne by the company even if it is in the interest of the shareholders.

In the context of the legal protection of the directors on the repurchase of shares that is canceled because of the law, every BOD's member is obliged to obey the rules of law (statutory duty). The meaning and aspect of 
other good faith in the context of the management of the company is submissive and obedient (obedience) to the law in general and to the statutory regulations and the company's articles of association in particular. Compliance with the laws and regulations to manage the company must be carried out in good faith, meaning that each BOD's member in carrying out the management of the company must carry out the provisions of the applicable laws and regulations (statutory duty).

\section{Conclusion}

The Board of Directors is jointly and severally liable for losses suffered by shareholders in good faith, arising from repurchases that are null and void due to the law. This does not provide fair/balanced legal protection for the parties. The fair value in buying shares is to provide balanced and proportional legal protection. Efforts to carry out reconstruction are primarily a form of legal protection that can be obtained fairly by the parties. This is where the researcher emphasizes the existence of the grounds that are used as a reason for the reconstruction of the roles and responsibilities of BOD in the repurchase of shares in a limited company based on fair values by carrying out reconstruction of Article 37 paragraph (3) of Law Number 40 Year 2007 Concerning Limited Liability Companies, that is: Before reconstruction: BOD is jointly and severally liable for losses suffered by shareholders in good faith, arising from repurchases that are null and void due to the law referred to in paragraph (2). After reconstruction: Article 37 paragraph (3) of Concerning Limited Liability Companies: BOD is jointly and severally liable for losses suffered by shareholders in good faith, arising from repurchases that are null and void due to the law referred to in paragraph (2) after a comparative study of the share repurchase. Addition to Article 37 (5) The share repurchase must be carried out carefully and transparently.

\section{References}

1. Ahmad Yani and Gunawan Widjaja, Limited Liability Company, Jakarta: PT. Raja Grafindo Persada, 2003

2. Bryan A. Garner, Black's Law Dictionary, Eight Edition, St. Paull-Minn: West Publishing, 2004

3. Chatamarrasjid, Breaking the Company's Veil and Actual Problems with Company Law, Bandung: Citra Aditya Bakti, 2004

4. Gunawan Widjaja, Board of Directors Responsibility for Bankruptcy of the Company, Jakarta: PT. Raja Grafindo Persada, 2003 http://www.tarjoni.com/aturan_buy_back_saham, accessed on October 14, 2018

5. I.G. Ray Wijaya, Corporate Law, Jakarta: Megapoint Division and Kesaint Blanc, 2000

6. Misahardi Wilamarta, Minority Shareholder Rights in the Context of Good Corporate Governance, Jakarta: Postgraduate Program, Faculty of Law, University of Indonesia, 2002

7. Munir Fuady, Limited Liability Company, New Paradigm, Bandung: Citra Aditya Bakti, 2003

8. Sally Putri, Juridical Review of the Buyback of Public Company Shares After the Establishment of the Financial Services Authority, Thesis, Medan: Universitas Sumatera Utara, 2014

9. Sulistyowati Irianto and Shidarta (ed), Legal Research Methods, Constellation and Reflection, Jakarta: Obor Indonesia Foundation, 2009 Law Number 40 of 2007 Concerning Limited Liability Companies 